\title{
ORGANIZATIONAL SUPPORT FOR TRAINING OF RUSSIAN SIGN LANGUAGE TRANSLATORS IN EDUCATIONAL INSTITUTIONS
}

\author{
APOIO ORGANIZACIONAL PARA A FORMAÇÃO DE TRADUTORES DE LÍNGUA \\ DE SINAIS RUSSA EM INSTITUIÇÕES DE EDUCAÇÃO
}

\author{
APOYO ORGANIZATIVO PARA LA FORMACIÓN DE TRADUCTORES DE LENGUA \\ DE SEÑAS RUSO EN INSTITUCIONES EDUCATIVAS
}

\author{
Olga O. AFANASYEVA ${ }^{1}$ \\ Anastasia V. KARPUNINA ${ }^{2}$ \\ Angelina A. KVITKOVSKAYA ${ }^{3}$ \\ Olga A. ANIKEEVA ${ }^{4}$ \\ Valeriya V. SIZIKOVA ${ }^{5}$
}

\begin{abstract}
Sign languages are a consequence of the development of modern society, confirmation of its inclusiveness, social orientation, attention to each member of society, regardless of his possibilities. The needs of society for knowledge of sign language are great, and not only because part of it cannot communicate in another way. But because such a knowledge of sign language is designed to eliminate and compensate for numerous barriers of interaction. The article contains materials for analysis of general principles of organizing training, legislatively enshrined conditions for organizing the process of training Russian sign language translators (RSL) based on secondary vocational or higher education institutions, as well as the experience of implementing such programs in various educational organizations. Induction, deduction, literature analysis, comparative analysis, unstructured observation is used as research methods. The result of the research will be a number of proposals based on teaching experience and regulatory documents that are recommended for use in the educational process. The authors offer their own vision of the organizational aspects, the provisions of which are advisable to use in organizing training for RSL translators.
\end{abstract}

KEYWORDS: Training of translators. Russian sign language. Educational process. Professional education.

RESUMO: As línguas de sinais são consequência do desenvolvimento da sociedade moderna, uma afirmação de sua inclusividade, orientação social, atenção a cada membro da sociedade, independentemente de suas possibilidades. As necessidades da sociedade por

\footnotetext{
${ }^{1}$ Russian State Social University (RSSU), Moscow - Russia. Candidate of Pedagogical Sciences. ORCID: https://orcid.org/0000-0002-7433-8974.E-mail: kop_olga15@mail.ru

2 Russian State Social University (RSSU), Moscow - Russia. Candidate of Sociological Sciences. ORCID: https://orcid.org/0000-0002-8302-0749. E-mail: karpunina@mail.ru

${ }^{3}$ Russian State Social University (RSSU), Moscow - Russia. Candidate of Pedagogical Sciences. ORCID: https://orcid.org/0000-0002-9505-6191.E-mail: eangelina@yandex.ru

4 Russian State Social University (RSSU), Moscow - Russia. Candidate of Historical Sciences. ORCID: https://orcid.org/0000-0001-7558-3149.E-mail: olga-double@mail.ru

5 Russian State Social University (RSSU), Moscow - Russia. Doctor of Pedagogical Sciences. ORCID: https://orcid.org/0000-0003-3991-3168. E-mail: 1699636@mail.ru
} 
conhecimento da língua de sinais são grandes, e não apenas porque parte dela não consegue se comunicar de outra forma. Mas porque tal conhecimento da linguagem de sinais é projetado para eliminar e compensar inúmeras barreiras de interação. $O$ artigo contém materiais para análise de princípios gerais de organização de formação, condições consagradas legislativamente para organizar o processo de formação de tradutores de língua russa de sinais (LRS) com base em instituições de ensino profissionalizante secundário ou superior, bem como a experiência de implementação de tais programas em várias organizações educacionais. A indução, a dedução, a análise da literatura, a análise comparativa e a observação não estruturada são utilizadas como métodos de pesquisa. $O$ resultado da pesquisa será uma série de propostas baseadas na experiência docente e em documentos normativos recomendados para uso no processo educacional. Os autores oferecem sua própria visão dos aspectos organizacionais, cujas disposições são aconselháveis para usar na organização de formação para tradutores da LRS.

PALAVRAS-CHAVE: Formação de tradutores. Lingua russa de sinais. Processo educacional. Formação profissional.

RESUMEN: Las lenguas de señas son consecuencia del desarrollo de la sociedad moderna, confirmación de su inclusividad, orientación social, atención a cada miembro de la sociedad, independientemente de sus posibilidades. Las necesidades de la sociedad por el conocimiento de la lengua de signos son grandes, y no solo porque parte de ella no pueda comunicarse de otra manera. Pero porque tal conocimiento del lenguaje de señas está diseñado para eliminar y compensar numerosas barreras de interacción. El artículo contiene materiales para el análisis de los principios generales de la organización de la formación, las condiciones consagradas legislativamente para organizar el proceso de formación de traductores de lengua de signos rusa (RSL) sobre la base de instituciones de educación secundaria profesional o superior, así como la experiencia de implementar dichos programas en diversas organizaciones educativas. La inducción, la deducción, el análisis de la literatura, el análisis comparativo y la observación no estructurada se utilizan como métodos de investigación. El resultado de la investigación serán una serie de propuestas basadas en la experiencia docente y documentos normativos que se recomiendan para su uso en el proceso educativo. Los autores ofrecen su propia visión de los aspectos organizativos, cuyas disposiciones es aconsejable utilizar en la organización de la formación de traductores de la RSL.

PALABRAS CLAVE: Formación de traductores. Lengua de signos rusa. Proceso educativo. Formación profesional.

\section{Introduction}

Knowledge of sign language, the ability to understand and use it, is a useful skill for any person. Of course, first of all, for people with hearing impairments themselves. Secondly, their social environment. Thirdly, specialists who work with deaf people and their families, for example, doctors, social workers, teachers. And everyone who works in the service sector. This indicates the importance of organizing training in sign language, starting with the training of translators on professional level.

RPGE- Revista on line de Política e Gestão Educacional, Araraquara, v. 25, n. esp. 3, p. 1605-1616, Sep. 2021. e-ISSN:1519-9029 DOI: https://doi.org/10.22633/rpge.v25iesp.3.15579 
Training of Russian sign language translators on higher level of education is just in the beginning of developing in Russia (KOSYANCHUK, 2020; SVINAREV, 2020; VLASOVA; KUDRYASHOVA; SEMENOVA, 2015), a full description is not found in the scientific literature at the moment. At the level of secondary vocational education, training programs for specialists in the organization of signage communication have been implemented for several years (Clarifications on the implementation of FSES, 2011), but we also did not find fundamental research in the scientific literature.

Our assumption that, in general, the preparation of RSL translators fits to the main outline of any educational program, however, there are a number of features dictated by the specifics of subject of study, teaching methods, such as a special mode of study.

\section{Methodology}

Subject of our research is the organizational aspects of the educational process at different levels of education of translators of RSL.

The research objectives are:

- $\quad$ highlighting the basic pedagogical principles of training translators of RSL;

- identification of basic concepts based on the analysis of regulatory documents for organization of educational process;

- analysis of our own experience, as well as the experience of colleagues in organizing the training of RSL translators;

- formulation of author's proposals on the issues studied and their comparison with the regulatory legislation.

The empirical basis of our study is educational organizations of Russia located in its different regions. The main source of data was the Russian State Social University (Moscow), which is a recognized leader in social education and training of students with hearing impairments. This university has a laboratory of Russian sign language. It has 216 students with hearing impairments (2021).

\section{Results}

\section{Normative regulation of educational process}

Organization of the process of training Russian sign language translators should obey certain general didactic principles that can be formulated based on the norms of educational 
legislation (Explanations on the formation of the curriculum, 2011; Federal Law N 296-FZ, 2012; Federal Law N 273-FZ, 2012; Letter of the Ministry of Education and Science of the Russian Federation No. 12-696, 2010; Letter of the Ministry of Education and Science of the Russian Federation No. 06-903, 2015; Order of the Ministry of Education and Science of the Russian Federation N 507, 2014; Order...N 885/390, 2020).

General didactic principles are the principle of conscientiousness and activity, scientific nature, systematicity, connection between theory and practice, visibility, strength, accessibility and an individual approach.

Scientific principle determines the mastery of elements of scientific knowledge about the world around them on a sign basis and familiarity with the elements of knowledge about sign language as a sign system.

Principle of systematicity assumes the formation of knowledge in a certain sequence, the purposeful enrichment of the ideas already existing, as well as continuity in the development of speech and logical knowledge and skills (i.e., their step-by-step build-up).

Principle of connection between theory and practice guarantees the mobility of the acquired knowledge, their practical application, the demand for knowledge and skills in a variety of activities.

Principle of strength obliges to provide conditions for meaningful assimilation and variable use of educational material.

Principle of visibility is very important for lesson organizing. The special meaning of its implementation is the possibility of activating speech activity, creating a situation where everyday experience is in demand: a picture or a natural object facilitates actualization, encourages remembering, telling, asking questions, denoting a situation given by grammatical means with a gesture for the subsequent establishment of linguistic patterns of sign language. The teacher directs the thoughts of children, pushes them to the necessary conclusions, generalizations.

Principle of accessibility means creating conditions for supporting and developing sign communication in the classroom. This principle establishes not only the degree of complexity of the educational material, but also its optimal sufficient volume, without which the speech development of students is impossible.

Principle of consciousness and activity implies the stimulation of independent mental activity, encouragement to questions, independent statements, priority of the child's active position. 
Individual approach in organizing experimental teaching of sign language has its specificity. The level of development of students' sign language is considered when determining the volume of theoretical information about sign language for assimilation.

Special principles are also implemented: principle of correctional orientation, the unity of teaching the basics of science, verbal speech and sign language, intensive development in activities, intensification of verbal communication.

System-forming principle is interactive teaching as a communicative dialogue with the use of methodological methods of speech development and familiarization with the environment known in the world practice.

An important role is played by the documents that determine the organization of the educational process: Federal State Educational Standard (FSES), basic professional educational program (BPEP), curriculum, and class schedule (LYSKOVA, 2017; VARINOVA, 2018). When forming them, it is necessary to take as a basis the corresponding state educational standard and educational programs developed in relation to its content.

Curriculum is a splitting of content of educational program by academic course, discipline and year of study. In educational institutions, as a rule, two types of curricula are developed and approved: prospective (for the entire period of study) and working (for the academic year). In vocational education institutions, curricula are drawn up for each area of formation (specialty).

\section{Organization of the educational process}

Duration of academic year in vocational education institutions is determined in accordance with the curriculum for certain areas of training or specialties. The start date of the academic year can be postponed in secondary specialized educational institutions for parttime evening education for no more than 1 month, for part-time education for no more than 3 months, and in universities - for no more than 2 months (by the decision of Academic Council). The minimum length of vacation is defined in the Model Regulations. So, students of secondary specialized educational institutions are provided with holidays at least twice during a full academic year with a total duration of 8-11 weeks per year, including at least 2 weeks in winter. For university students, the duration of holidays during the academic year is at least 7 weeks, of which at least 2 weeks - in winter (Letter of the Ministry of Education and Science of the Russian Federation No. 12-696, 2010; Letter of the Ministry of Education and Science of the Russian Federation No. 06-903, 2015). 
Based on the curricula of educational process, a schedule of classes is drawn up for a certain period, for example, a semester (in vocational education institutions). The main types of training are determined by the Standard Regulations on educational institutions and local acts of institutions. For example, regarding the direction of training "Organization of signage communications" in secondary educational institutions, the following main types of training are established: lecture, practical lesson, test work, consultation, independent work, industrial (professional) practice, coursework (course design), graduation qualification work (diploma project, diploma thesis), as well as other types of training sessions can be conducted. Similar types of training are conducted in universities. For all types of classroom studies, an academic hour is the duration established. In institutions of secondary vocational education, it is 45 minutes, while in universities it can increase up to 50 minutes (LYSKOVA, 2017).

Regarding the sequence of modules or disciplines in semesters, the basic principle that should not be violated is the principle of logical consistency and continuity.

Legislation, local regulations of educational institutions, as well as agreements on the provision of educational services determine the specifics of the organization of the educational process in obtaining education in various forms (correspondence, part-time, selfeducation and external studies).

\section{Requirements for institutions}

Mastering educational programs requires considerable efforts and time from students (ZIKRATOV, 2018). According to the experience of teaching RSL, the duration of 1 lesson cannot be more than 1.5 hours. The break must be at least 15 minutes. After two 1.5 hour sessions, a break must be made of at least 1 hour. A prerequisite for rest is distraction from the subject of study and switching attention. These provisions are especially relevant at the stage of the first acquaintance with the vocabulary. The maximum load in 1 day cannot exceed four sessions of 1.5 hour each (LIPINA, 2018; ARSKIY, 2020).

In requirements for organization of educational process, one can also distinguish rules on the maximum occupancy of groups. Their observance is not only of medical and hygienic importance, but also allows to ensure the effectiveness of the educational process, good assimilation of the material, current control of knowledge, the organization of optimal interaction between students and the teacher during classes. In the case of organizing sign language training, the number of people in the group should not exceed 8-10 people. This norm is due to the fact that sign language is quite difficult to learn, because in addition to the 
auditory and visual, a great load falls on the motor and speech motor functions of the body. At the same time, sign language is a foreign language for students (ALIKINA, 2017), therefore, the filling rate should be regulated by legislation related to the formation of foreign language learning groups. In the study of a spoken foreign language, only two are involved: the auditory and visual functions. In the study and practical application of the Russian sign language, 3 functions and 3 analyzers are involved: auditory, visual and motor and, accordingly, auditory, visual and motor memory (AFANASYEVA, 2018; KOPNINA, 2015).

Learning process is not limited to the verbalization of the material. The teacher needs constant tactile contact with students: setting fingers (fingerprinting), practicing gesture components (configuration, location, movement and features of hand movement), controlling the correct demonstration of the gesture from several angles (as a 3D format), practicing correct articulation and non-manual components gesture. Moreover, it is necessary to develop and practice the receptive and expressive skills of students from the very first stage of training. In the case of an increase in the group, the quality of teaching decreases in a mathematical progression because the individual-collective time for working out and controlling practical skills increases. Quizzes of all students at the same time (written work on the material) in this type of training are not used. The same features of the study of sign language determine the obligatory circular landing of students - the teacher must see the synchronous execution of elements of a gesture, a phrase. In turn, students must see the teacher and his hands as close as possible, and also see each other and each other's hands, because in this case, eye contact of all participants in the educational process is required (ALIKINA, 2017).

Training program for mid-level specialists should ensure:

- implementation of practical exercises;

- training in educational which fits to educational goals (Clarifications on the implementation of FSES, 2011).

Regarding sign language, it should be noted that the use of distance technologies is impractical and has an inverse correlation with the quality of learning the material. Elements of e-learning (video) can be used as material for research and analysis by students, as an example of the work of a translator, but nothing more. Video training without feedback and the ability to observe students in different projections does not lead to a significant result (ALIKINA, 2017). 


\section{Assessment of formed competencies}

Assessment funds are created to monitor and evaluate the results of study. Forms and methods of control and assessment of the formed competencies of future Russian sign language translators can be testing for knowledge of the theoretical foundations of translation activities, a written examination for knowledge of the theoretical foundations of translation activities, demonstration of translation (direct consecutive, reverse consecutive, direct simultaneous, reverse synchronous), assessment of the submitted translation texts in a practical lesson, expert assessment of the implementation of translations of various types (forward sequential, reverse sequential, forward synchronous, reverse synchronous). The result of mastering the professional module should be an assessment of the student's readiness to perform a specific type of professional activity with the assessment «The type of professional activity mastered/not mastered».

Practical training of students on the profile "Organization of signage communications" can be organized:

1) directly in an organization that carries out educational activities, if students who are carriers of RSL study in this organization;

2) in an organization carrying out activities in the profile of the relevant educational program (hereinafter - profile organization), including in the structural unit of the profile organization intended for practical training, based on an agreement concluded between the educational organization and the profile organization (Order of the Ministry of Science and Higher Education of the Russian Federation and the Ministry of Education of the Russian Federation N 885/390, 2020).

When implementing the training program for specialists in the field of organizing signage communications, the FSES for the following types of practices: educational and production.

Practice consists of two stages: practice according to the profile of the specialty and pre-diploma practice. Attestation based on the results of industrial practice is carried out considering (or based on) the results, confirmed by the documents of the relevant organizations.

\section{Discussion}

Professional education is a good base for training of translators. But what about specifics of educational process in universities? Higher education in Russia is free of charge 
and the annual competition for universities is very high. Many students want a college degree and hearing-impaired students are a very sensitive group, prone to many turbulences. Admitting a student with a hearing impairment is a responsible act for the university, requiring many efforts.

Structure of the bachelor's program includes a mandatory part (basic) and a part formed by universities (variable). It is possible to implement bachelor's programs with a different focus (profile) of education within one direction of training.

The university is obliged to form the socio-cultural environment, to create the conditions necessary for the comprehensive development of the personality of future translators. Competence-based approach should provide wide use of active and interactive forms in combination with extracurricular work in order to form and develop professional skills of students. Within the framework of training courses, meetings with representatives of Russian and foreign companies, government and public organizations, master classes by experts and specialists should be provided (MINAEVA, 2020).

The proportion of classes conducted in interactive forms is determined by the main goal (mission) of the program, the peculiarity of the contingent of students and the content of specific disciplines, and in general, in the educational process, they should be at least $20 \%$ $(10 \%)$ of classroom lessons. Lecture-type lessons for the corresponding groups of students cannot be more than $40 \%(45 \%)$ of classroom lessons. In the total number of classes in disciplines related to RSL, the proportion of interactive classes should be at least $60 \%$, lectures - no more than $20 \%$.

The curriculum of each discipline (module, course) should clearly formulate the final learning outcomes.

Then the curriculum is developed; the schedule of the educational process, including the calendar schedule; list of practice bases; BRI staffing table; regulations on the organization of the educational process at the university using the credit system and regulations on the modular organization of the educational process.

An obligatory component of educational program is the practical training of students. Goals and objectives of practice are determined by federal state educational standards of higher education. 


\section{Conclusion}

Training of Russian sign language translators is an important area of training that has not only practical but also social significance. But this educational process requires a special approach, compliance with special requirements, recommendations and conditions. Contemporary educational institutions are trying to make great effort to develop this area of training, to fulfill all the conditions and comply with the requirements for the organization of the educational process. These organizational conditions are provided for by the existing legislation, however, it should be noted that this is not enough for the high-quality organization of training for Russian sign language translators. For example, there are serious inconsistencies in the federal state educational standard "Organization of deaf communications", the elimination of which will inevitably entail changes in the organization of the educational process in colleges and universities. There are no normatively fixed norms for the size of student groups, which is extremely important in teaching Russian sign language translators. At the moment, the transition of the educational process to the online mode has become a serious problem, which catastrophically affects the quality of training of specialists in communication and translation. All the difficulties that arise make it necessary to continue developing recommendations for organizing training for Russian sign language translators.

\section{REFERENCES}

AFANASYEVA, O.O. The system of independent certification of sign language translators. Proceedings of the Central Research Institute of Russian Sign Language: Materials of the Scientific and Practical Conference, pp. 147-150, 2018.

ALIKINA, E.V. Concept of teaching translators in the system of higher linguistic education on the basis of an integrative approach. Nizhny Novgorod: Nizhny Novgorod State Linguistic University, 2017.

ARSKIY, A.A. Actual problems of teaching Russian sign language to police officers. Scientific component, v. 1, n. 5, pp. 111-118, 2020.

Clarifications on the implementation of FSES of secondary (complete) general education (specialized training), formed on the basis of the FSES NiSPE. Approved by the NMS of the Center for Primary, Secondary, Higher and Additional Education FSI "FIRO", Protocol No. 1, February 3, 2011.

Explanations on the formation of the curriculum for the OBEP NiSPO. Approved by the NMS of the Center for Primary, Secondary, Higher and Additional Education of the Federal State Institution "FIRO", Protocol No. 1, February 3, 2011. 
Federal Law N 273-FZ. "On Education in the Russian Federation", December 29, 2012. Retrieved from: https://rg.ru/2012/12/30/obrazovanie-dok.html

Federal Law N 296-FZ. "On Amendments to Articles 14 and 19 of the Federal Law" On Social Protection of Disabled People in the Russian Federation", December 30, 2012.

KOPNINA, O.O. Training of specialists to work with deaf-blind citizens (experience of social partnership). Russian science and education today: problems and prospects, v. 3, n. 6, pp. 72-74, 2015

KOSYANCHUK, A.S. On the creation of optimal psychological and pedagogical conditions and the use of modern methods of teaching Russian sign language. Scientific Digest of the East Siberian Institute of the Ministry of Internal Affairs of Russia, v. 1, n. 4, pp. 154$159,2020$.

Letter of the Ministry of Education and Science of the Russian Federation No. 12-696. "On clarifications on the formation of the curriculum for OBEP NISPO", October 20, 2010.

Letter of the Ministry of Education and Science of the Russian Federation No. 06-903. "On the direction of methodological recommendations for updating the current federal state educational standards of secondary vocational education, taking into account the accepted professional standards", August 5, 2015.

LIPINA, E.A. From the experience of teaching Russian sign language to police officers in the system of additional professional education. Psychopedagogy in law enforcement agencies, v. 1, n. 72, pp. 79-85, 2018.

LYSKOVA, M.I. Organizational and methodological foundations of teaching Russian sign language to employees of internal affairs bodies of the Russian Federation. Bulletin of the Tyumen Institute for Advanced Training of Employees of the Ministry of Internal Affairs of Russia, v. 1, n. 8, pp. 183-189, 2017.

MINAEVA, E.S. Motivational criteria for the formation of readiness for professional activity of Russian sign language translators. Society: sociology, psychology, pedagogy, v. 7, n. 75, pp. 113-117, 2020.

Order of the Ministry of Education and Science of the Russian Federation N 507. "On approval of the federal state educational standard of secondary vocational education in the specialty 39.02.02 Organization of signage communication", May 12, 2014.

Order of the Ministry of Science and Higher Education of the Russian Federation and the Ministry of Education of the Russian Federation N 885/390. "On the practical training of students", August 5, 2020.

SVINAREV, S.V. Problems of teaching Russian sign language in the system of higher educational institutions of the Ministry of Internal Affairs of Russia on vocational training programs. Questions of pedagogy, v. 1, n. 1-2, pp. 222-226, 2020.

VARINOVA, O. A. Requirements for the profession of a translator of Russian sign language in modern conditions. Scientific works of the Central Research Institute of 
Russian Sign Language: Materials of the Scientific and Practical Conference, pp. 159-168, 2018.

VLASOVA, L.P., KUDRYASHOVA, E.M., SEMENOVA, N.A. Training of sign language translators. Theoretical and practical issues of psychology and pedagogy: a collection of articles of the International scientific-practical conference, pp. 80-85, 2015.

ZIKRATOV, V.V. On models of teaching Russian sign language. Science. Education.

Culture. Actual problems and practice of solution (federal and regional aspects): collection of works of the XI All-Russian scientific-practical conference with international participation, pp. 10-13, 2018.

\section{How to reference this article}

AFANASYEVA, O. O.; KARPUNINA, A. V.; KVITKOVSKAYA, A. A.; ANIKEEVA, O. A.; SIZIKOVA, V. V. Organizational support for training of Russian Sign Language translators in educational institutions. Revista on line de Política e Gestão Educacional, Araraquara, v. 25, n. esp. 3, p. 1605-1616, Sep. 2021. e-ISSN:1519-9029. DOI: https://doi.org/10.22633/rpge.v25iesp.3.15579

Submitted: $20 / 03 / 2021$

Required revisions: 05/06/2021

Approved: $12 / 07 / 2021$

Published: 01/08/2021 